\title{
Molecular Cloning of Streptococcus bovis Lactose Catabolic Genes
}

\author{
By HARRY J. GILBERT* AND JUDITH HALL \\ Department of Agricultural Biochemistry and Nutrition, University of Newcastle, \\ Newcastle upon Tyne NE1 7RU, UK
}

(Received 18 February 1987; revised 6 April 1987)

\begin{abstract}
The hydrolysis of lactose in Streptococcus bovis was shown to be catalysed by $\beta$-D-galactosidase. To isolate lactose catabolic genes, a gene library of $S$. bovis DNA was constructed in bacteriophage $\lambda 47.1$ and recombinants expressing $\beta$-D-galactosidase activity were detected using 5-bromo-4-chloro-indoyl- $\beta$-D-galactoside (X-Gal). The gene was cloned on a $7 \cdot 8 \mathrm{~kb}$ DNA restriction fragment into pBR322 to generate the recombinant plasmid pHG1, which also encoded $S$. bovis lactose permease, thiogalactoside transacetylase and lactose repressor protein. The position and orientation of the four genes were determined by subcloning and transposon mutagenesis. The $\beta$-D-galactosidase, lactose permease and thiogalactoside transacetylase genes constitute an operon controlled by the repressor protein. $\beta$-D-Galactosides induced expression of the $S$. bovis lac genes in Escherichia coli while glucose had no effect. The nucleotide sequence of the presumptive regulatory region of the $S$. bovis lac operon was determined and compared with the corresponding $E$. coli sequence. The operators and the $5^{\prime}$ end of the lac $Z$ genes showed strong identity. The catabolite activator protein binding sequence, present in the $E$. coli promoter, was absent from the corresponding $S$. bovis region.
\end{abstract}

\section{INTRODUCTION}

It has recently been suggested that the genetic manipulation of certain rumen bacteria could result in an enhanced efficiency of livestock production (Smith \& Hespell, 1983; Armstrong \& Gilbert, 1985). Progress in this field is hampered by the limited genetic analysis of important rumen bacteria; consequently, we have initiated studies on the regulation of gene expression in the prominent rumen micro-organism Streptococcus bovis. Of particular interest is the characterization of genes involved in lactose catabolism. In most enterobacteria there are three lac genes organized in an operon. The closely linked lacI gene encodes a protein which represses lac gene expression. Some $\beta$-D-galactosides inactivate the repressor protein and so induce synthesis of the Lac proteins (Miller, 1978). Glucose represses expression of the lac operon by reducing cAMP concentrations. This metabolite activates the catabolic activator protein (CAP) which binds to the lac $Z p$ region and stimulates transcription of the operon. In Staphylococcus aureus, Lactobacillus casei and several streptococcal strains lactose is metabolized by a different pathway (Hengstenberg et al., 1969). The sugar is phosphorylated during transport across the bacterial cell membrane. Cleavage by phospho- $\beta$-D-galactosidase yields glucose and galactose 6phosphate. The latter is converted to dihydroxyacetone phosphate by three enzyme-catalysed reactions (Maeda \& Gasson, 1986). Enzymes involved in this lactose catabolic pathway are plasmid-encoded in several Gram-positive bacteria (Lee et al., 1982). The regulation of expression of these lactose metabolism genes is complex. In Staphylococcus aureus, galactose 6phosphate is an inducer while in Streptococcus lactis expression appears to be regulated more by a repression due to the growth substrate. In $L$. case $i$ a $\beta$-galactoside is required for induction. In

Abbreviations: IPTG, isopropyl thio- $\beta$-galactoside; X-Gal, 5-bromo-4-chloro-indoyl- $\beta$-D-galactoside 
all these organisms glucose represses the expression of the lactose genes (Lee et al., 1982). The lactose catabolic pathway in $S$. bovis is unknown.

The aim of this study was to isolate and characterize the lactose catabolic genes from $S$. bovis.

\section{METHODS}

Microbial strains and plasmids. These are listed in Table 1. Bacteriophage were grown in Escherichia coli strains Q359, LE392 or MC1061, as described by Maniatis et al. (1982).

Media. E. coli strains were cultured in L-broth ( $1 \%$ tryptone, $0.5 \%$ yeast extract, $0.5 \% \mathrm{NaCl}) . S$. bovis was grown in medium described by Silley \& Armstrong (1984). Media were solidified with the addition of either $2 \%(\mathrm{w} / \mathrm{v})$ Bacto-agar (Difco) or $0.8 \%$ agarose (Pharmacia). Glucose or glycerol, when required, were added to media at a final concentration of $2 \mathrm{mg} \mathrm{ml}^{-1}$. Ampicillin $\left(100 \mu \mathrm{g} \mathrm{ml}^{-1}\right)$ was used in media for the selection and growth of transformants. Functional $\beta$-D-galactosidase was detected by the addition of 5 -bromo-4-chloro-indoyl- $\beta$-Dgalactoside (X-Gal) to a final concentration of $40 \mu \mathrm{g} \mathrm{ml} l^{-1}$.

Chemicals. $[\alpha-32$ P]ATP and the in vitro packaging kit were from Amersham. Restriction enzymes, DNA polymerase, DNAase and T4 DNA ligase were from BRL. X-OMAT RP X-ray film was from Kodak. Pharmacia supplied agarose. BA85 nitrocellulose filters were obtained from Schleicher and Schuell. All other reagents were from Sigma or BDH.

DNA isolation. (i) $S$. bovis DNA. Cells of $S$. bovis (10 g wet wt) grown to early stationary phase were harvested, washed three times with ice-cold $2 \mathrm{M}-\mathrm{NaCl}$, resuspended in $20 \mathrm{ml} 50 \mathrm{mM}$-Tris $/ \mathrm{HCl}$ buffer, $\mathrm{pH} 8.0$, containing $25 \%$

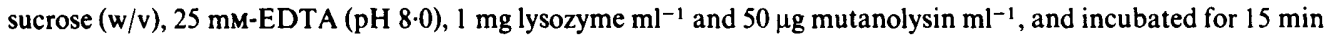

Table 1. Microbial strains and plasmids used in this work

Bacteria, bacteriophage or plasmid

Genotype or phenotype

Source or reference

E. coli $\mathrm{K} 12$

W3110

CA159

LE392

MC1061

JM101

Q359

NH4110

S. bovis

$\mathrm{H} / 3$

Bacteriophage

$\lambda 47.1$

M13mp8

M13mp9

Plasmids

pACYC184

pBR322

pUC19

pNM52

pNM480, pNM481, pNM482

pHG1, pHG2

pHG3, pHG4, pHG5

pHG6, pHG7

pHG8

pHG9

pHG 10
Prototrophic

lacI

hsdR514 supE44 supF58 lac Y1 galK2

galT22 metBI trpR55

hsdR rpsL araD139 $\Delta($ ara-leu $) 7697$

$\Delta$ lac 74 galU

$\Delta\left(\right.$ lac-pro) thi rpsL supE hsdR $\mathrm{F}^{\prime}$ traD36

proAB lac $^{9} \Delta M 15$

$h d s R_{\mathrm{K}} \operatorname{supF}\left(\mathrm{P}^{+}\right)$

Harbours F plasmid carrying $\operatorname{Tn} 1000$ sequence

$\mathrm{Tet}^{+} \mathrm{Cat}^{+}$

$\mathrm{Bla}^{+} \mathrm{Tet}^{+}$

Bla ${ }^{+}$lac Z'

E. coli lacI ${ }^{\natural} \mathrm{Tet}^{+}$

$\mathrm{Bla}^{+}$lac Z'

$\mathrm{Bla}^{+}$. pBR322 containing S. bovis lac genes

Bla ${ }^{+}$. Derivatives of $\mathrm{pHGl}$ with

deletions of part of $S$. bovis DNA

$\mathrm{Bla}^{+}$. Fragments of $\mathrm{pHGl}$ cloned into pUC19

$\mathrm{Cat}^{+}$. Derivative of pACYCl84

containing $S$. bovis lacI gene

$\mathrm{Bla}^{+}$. pHG $1:: \operatorname{Tn} 1000$ with insertion at

position 1.5

$\mathrm{Bla}^{+}$. pNM480 containing $S$. bovis lacZpo
This laboratory

This laboratory

This laboratory

Minton (1984)

Viera \& Messing (1982)

Gilbert et al. (1985)

Guyer (1978)

Silley \& Armstrong (1984)

Loenen \& Brammar

(1980)

Viera \& Messing (1982)

Viera \& Messing (1982)

Chang \& Cohen (1978)

Bolivar et al. (1977)

Norrander et al. (1983)

Gilbert et al. (1986)

Minton (1984)

This work 
at $37^{\circ} \mathrm{C}$. After lysis of the cells by the addition of SDS to a final concentration of $1 \%$, DNA was extracted as described by Gilbert et al. (1985).

(ii) Plasmid DNA. E. coli plasmids were purified from 1 litre L-broth cultures as described by Clewell \& Helinski (1969). The rapid boiling method of Holmes \& Quigley (1981) was used for small scale isolation for screening purposes.

Construction of a phage library of S. bovis DNA and screening of the library for the streptococcal $\beta$-D-galactosidase gene. S. bovis DNA was partially digested with Sau3A. DNA fragments $9-20 \mathrm{~kb}$ in size were purified by agarose gel electrophoresis and ligated to $\lambda 47.1$ DNA cleaved with BamHI. The DNA was in-vitro-packaged and the Spiphenotype of recombinant phage was selected by growth on the E. coli P2 lysogen Q359 (Loenen \& Brammar, 1980).

For screening the library, recombinant phages were grown on the $l a c^{-} E$. coli strain MC1061 to a density of 100 plaques $\mathrm{cm}^{-2}$. X-Gal was added to the top agar $\left(40 \mu \mathrm{g} \mathrm{m}^{-1}\right)$ and recombinant phages, expressing $\beta$-Dgalactosidase, were detected by the blue colour of plaques.

Transposon mutagenesis with Tn1000. This was done as described by Guyer (1978). Transposon insertion sites were located by isolating plasmid DNA and restricting separately with EcoRI, BamHI and HindIII.

Southern blot hybridization. S. bovis DNA, digested to completion with HindIII and EcoRI, was fractionated by agarose gel electrophoresis and transferred to nitrocellulose filters (Southern, 1975). DNA probes were labelled by nick-translation (Rigby et al., 1977) to a specific activity of $1-4 \times 10^{8}$ c.p.m. ( $\mu$ g DNA) $)^{-1}$. Conditions for hybridization and subsequent washing of filters were as described by Maniatis et al. (1982).

General recombinant DNA procedures. Restriction endonuclease and T4 DNA ligase were used according to the manufacturer's instructions. Transformation of $E$. coli was as described by Cohen et al. (1972). DNA was electrophoresed in agarose gels $(0.8 \%-1.5 \%)$ using a Tris/borate/EDTA buffer (Meyers et al., 1976). $\lambda$ DNA digested with HindIII, or HindIII and EcoRI, was used as a molecular size standard. DNA sequencing was done as described by Sanger et al. (1980).

Construction of pHG8. A $3 \mathrm{~kb}$ HindIII/KpnI restriction fragment carrying the $S$. bovis lacI gene was purified from pHG 1 and the $5^{\prime}$ and $3^{\prime}$ protruding termini blunt-ended with T4 polymerase in the presence of all four deoxynucleotide triphosphates. The resultant DNA was cloned into the EcoRV site of pACYC184 to generate pHG8.

Enzyme and protein assays. $\beta$-D-Galactosidase, lactose permease and thiogalactoside transacetylase were assayed by the method of Miller (1972). $\beta$-D-Phosphogalactosidase was determined by the method of Maeda \& Gasson (1986). One unit of enzyme activity converts $1 \mathrm{nmol}$ of substrate to product $\mathrm{min}^{-1}$. Protein was measured by the Lowry method.

\section{RESULTS}

Detection of $\beta$-D-galactosidase and $\beta$-D-phosphogalactosidase in $S$. bovis

$S$. bovis, grown on minimal medium with lactose as sole carbon source, was assayed for $\beta$-Dgalactosidase and $\beta$-D-phosphogalactosidase. Only the former enzyme activity was detected (Table 2). To investigate whether $\beta$-D-galactosidase was induced by $\beta$-D-galactosides, $S$. bovis was grown on glycerol minimal medium to early stationary phase, transferred to media containing potential inducers and repressors of lactose catabolism, and assayed for $\beta$-Dgalactosidase. The results (Table 2 ) showed that little $\beta$-D-galactosidase activity was detected in the absence of $\beta$-D-galactosides. Isopropyl thio- $\beta$-galactoside (IPTG) was a stronger inducer of the enzyme than lactose. Glucose, but not glycerol, repressed $\beta$-D-galactosidase synthesis.

\section{Table 2. $\beta$-D-Galactosidase and phospho- $\beta$-D-galactosidase in $S$. bovis}

Cells of $S$. bovis, grown to early stationary phase in glycerol minimal medium, were transferred to media supplemented with various metabolites. After $3 \mathrm{~h}$, cells were harvested and lysed as described in Methods; DNA was degraded with DNAase and bacterial debris removed by centrifugation at $15000 \mathrm{~g}$ for $5 \mathrm{~min}$. Enzymes were assayed as described in Methods.

Addition to growth medium

None

Lactose $(0.2 \%)$

IPTG (1 mM)

IPTG $(1 \mathrm{~mm})+$ glucose $(0 \cdot 2 \%)$
$\beta$-D-Galactosidase

[Units (mg protein $)^{-1}$ ]

17

250

3300

910
$\beta$-D-Phosphogalactosidase

[Units (mg protein) ${ }^{-1}$ ] 
Table 3. Expression of $S$. bovis lac genes in E. coli

Plasmids were inserted into $E$. coli $\mathrm{MC1061}$. The growth of recombinant strains and preparation of cellfree extracts were as described by Gilbert et al. (1986). The lac gene proteins were assayed as described in Methods. E. coli strain W3110 was used as a control to determine glucose repression of the $E$. coli lac operon. ND, Not determined.

\begin{tabular}{|c|c|c|c|c|}
\hline Plasmid & $\begin{array}{l}\text { Addition to } \\
\text { growth medium }\end{array}$ & $\begin{array}{c}\beta \text {-D-Galactosidase } \\
\left.[\text { Units (mg protein) })^{-1}\right]\end{array}$ & $\begin{array}{c}\text { Lactose permease } \\
\left.\text { [Units (mg protein) })^{-1}\right]\end{array}$ & $\begin{array}{c}\text { Thiogalactoside } \\
\text { transacetylase } \\
\text { [Units (mg protein) })^{-1} \text { ] }\end{array}$ \\
\hline pUC19 & IPTG & 0 & 0 & 0 \\
\hline pBR322 & IPTG & 0 & 0 & 0 \\
\hline pHGl & - & 22 & $2 \cdot 4$ & $1 \cdot 1$ \\
\hline pHGl & Lactose & 300 & 91 & 43 \\
\hline pHGI & IPTG & 3320 & 1060 & 680 \\
\hline pHGi & IPTG + glucose & 4010 & ND & ND \\
\hline pHG2 & - & 18 & $1 \cdot 1$ & 0.7 \\
\hline pHG2 & IPTG & 4130 & 1230 & 640 \\
\hline $\mathrm{pHG} 3$ & IPTG & 3670 & 920 & 0 \\
\hline pHG4 & IPTG & 0 & 0 & 0 \\
\hline pHG5 & IPTG & 0 & 0 & 0 \\
\hline pHG6 & IPTG & 4360 & 0 & 0 \\
\hline pHG7 & IPTG & 0 & 0 & 0 \\
\hline pHG9 & - & 5100 & 1700 & 730 \\
\hline pHG9 & IPTG & 5250 & 1790 & 800 \\
\hline pHG $8 / p H G 9$ & - & 19 & $2 \cdot 1$ & 0.2 \\
\hline pHG $8 / \mathrm{pHG} 9$ & IPTG & 2820 & 720 & 310 \\
\hline pHG8 & IPTG & 0 & 0 & 0 \\
\hline- & IPTG & 45000 & ND & ND \\
\hline - & IPTG + glucose & 8500 & ND & ND \\
\hline
\end{tabular}

Isolation of the S. bovis lac genes

A gene library of $S$. bovis DNA was constructed in bacteriophage $\lambda 47.1$ and a total of 11000 recombinants were isolated. The recombinant gene bank was screened as described in Methods for phages which synthesized $S$. bovis $\beta$-D-galactosidase. Approximately 35 phages were shown to degrade $X-G a l$. DNA was extracted from five of these phages and digested with various restriction enzymes. A $7.8 \mathrm{~kb}$ HindIII DNA fragment, common to four of the five phages, was subcloned into the HindIII site of pBR322 in both orientations to yield recombinant plasmids pHG1 and pHG2. Cells of $E$. coli $\mathrm{MC} 1061$ harbouring either plasmid synthesized $S$. bovis $\beta$-Dgalactosidase, lactose permease and thiogalactoside transacetylase (Table 3 ) as well as growing on minimal media containing lactose as sole carbon source. The cleavage sites of different restriction enzymes were mapped within the $S$. bovis DNA present in pHGl (Fig. 1).

\section{Subcloning and orientation of the lac genes}

The positions of the lac genes within the $7.8 \mathrm{~kb}$ HindIII fragment were determined by a combination of transposon mutagenesis and the deletion and subcloning of various restriction fragments into $\mathrm{pUC19}$, followed by determination of $\beta$-D-galactosidase, lactose permease and thiogalactoside transacetylase activities (Fig. 1). Partial digestion, with EcoRI, and religation of pHG1, generated plasmids pHG3, pHG4 and pHG5. No functional lac genes were present in pHG4 and pHG5. Recombinant plasmid pHG3 contained functional $\beta$-D-galactosidase and lactose permease genes. When the HindIII-Pst I (0-6.5) fragment was subcloned into pUC19, cells of $\mathrm{MCl} 1061$ carrying the recombinant plasmid (pHG6) produced $\beta$-D-galactosidase but no lactose permease or thiogalactoside transacetylase. When the KpnI-HindIII (3.0-7.8) fragment was subcloned into pUC19 the resultant recombinant plasmid, pHG7, did not contain any functional lac genes. Transposon mutagenesis between map positions 0-2.3 did not inactivate any of the lac genes, while Tn 1000 insertions between map position 2.7 and the EcoRI (5.5) restriction site inactivated all three genes. Mutations of sequences between map positions 5.7 and 6.6 inactivated the lactose permease and thiogalactoside transacetylase genes. Transposons 


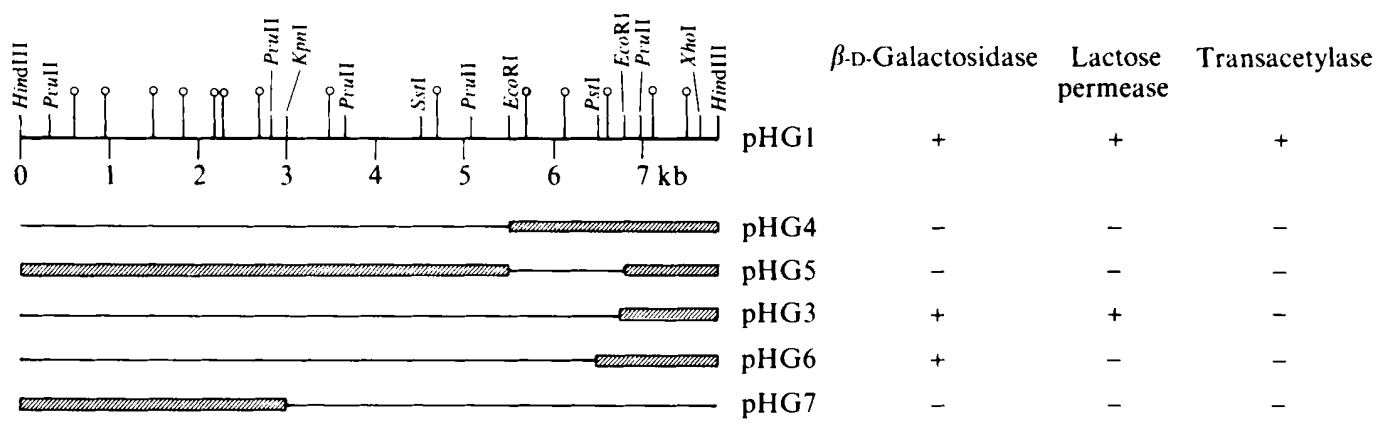

Fig. 1. Restriction, deletion and transposon mutagenesis map of $S$. bovis DNA cloned in pHG1. The cleavage sites of restriction enzymes EcoRI, HindIII, PstI, XhoI, SstI, PvuII and KpnI are shown. The following enzymes did not cleave the DNA: BamHI, SalI, XbaI, XmaI, BglII and ScaI. O, Tn 1000 transposon insertion sites. $\mathbb{N}$, Regions of deleted $S$. bovis DNA in plasmids derived from pHGl - the enzyme activities which these plasmids confer on $E$. coli $\mathrm{MC1061}$ are shown.

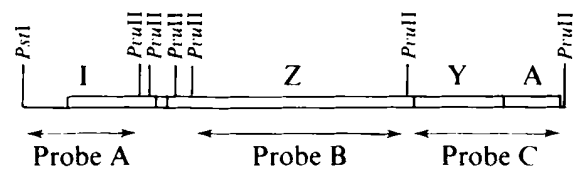

Fig. 2. Derivation of hybridization probes. The PvuII and Pst I cleavage sites in the E. coli lac operon were determined by Chaconas et al. (1981). Probe A was obtained from pNM52 (Gilbert et al., 1986) while probes B and C were derived from pNM480 (Minton, 1984).

inserted into DNA between the EcoRI (6.8) and HindIII (7.8) restriction sites only inactivated the transacetylase gene.

The above data locate the $\beta$-D-galactosidase gene in a region between map positions 2.3 and 5.7 , the lactose permease gene between map positions 5.5 and 6.8 and the transacetylase gene between the EcoRI (6.8) and HindIII (7.8) restriction sites. Removal or mutagenesis of the $\beta$-Dgalactosidase gene inactivates the other two lac genes. Interruption of the lactose permease gene has a polar effect on the transacetylase gene. Alteration of the latter sequence does not reduce expression of the other lac genes. These data indicate that the lac genes are under operon control with the direction of transcription running from the $\beta$-D-galactosidase locus to the transacetylase gene.

\section{Homology of $S$. bovis and $E$. coli lac genes}

Homology studies were done, using $P v u I I$ and $P v u I I / P s t I$ DNA restriction fragments from the $E$. coli operon as probes. The derivation of probes A, B and C is shown in Fig. 2. Southern hybridization of the three probes to HindIII and EcoRI digests of S. bovis DNA (Fig. 3) showed that the E. coli lac Z gene hybridized (even at high stringency) to $7.8 \mathrm{~kb} H$ indIII and $5.5 \mathrm{~kb} E c o$ RI DNA restriction fragments. Neither of the other probes hybridized to $S$. bovis DNA under the conditions used. Thus, the E. coli lac $Z$ gene shows homology to the corresponding $S$. bovis gene.

\section{Regulation of $S$. bovis lac genes in E. coli}

To determine whether the $S$. bovis lac operon was induced in $E$. coli, cells of MC1061 harbouring pHGl were grown in medium containing $\beta$-D-galactosides and lactose catabolic activities determined. Results (Table 3 ) showed that in the presence of lactose and IPTG there was a 20-fold and 200-fold increase, respectively, of the lac gene products. Derivatives of pHG1, containing $\mathrm{Tn} 1000$ insertions between map positions 1.0 and $2 \cdot 3$, when introduced into $\mathrm{MC} 1061$ resulted in the constitutive synthesis of lac gene products. These data indicate that a region of DNA upstream of the $\beta$-D-galactosidase gene plays an important role in repressing the lac operon. To determine whether this locus was cis or trans acting, the plasmid pHG8 (a multicopy plasmid carrying the $3 \mathrm{~kb} K p n I-H i n d I I I$ fragment of pHGl, which is compatible with vectors 
Probe...

A

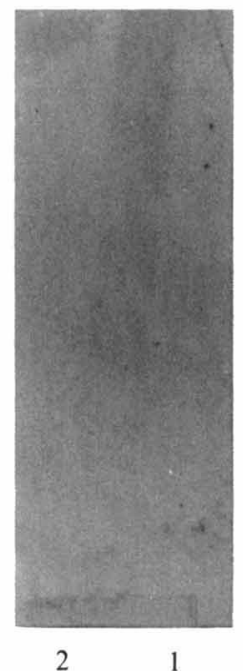

B

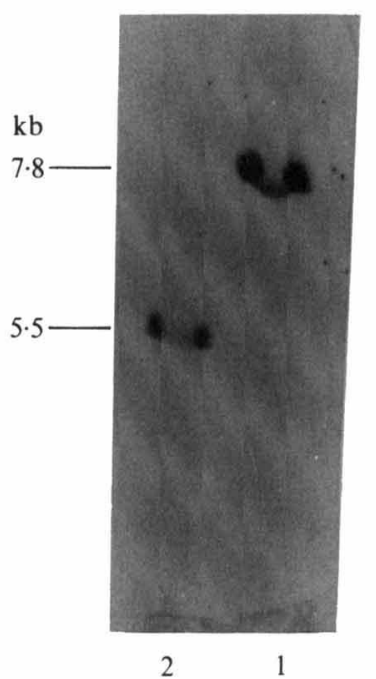

C

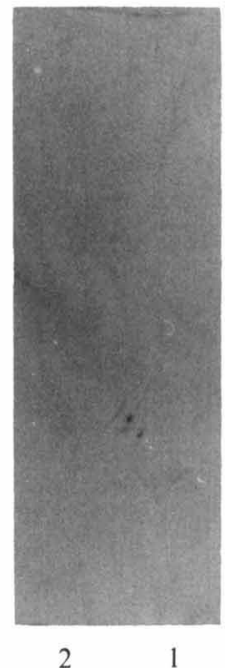

Fig. 3. Hybridization of E. coli lac operon DNA probes to $S$. bovis DNA. Chromosomal $S$. bovis DNA, digested with HindIII (1) and EcoRI (2), were transferred from agarose gels to nitrocellulose filters and hybridized to ${ }^{32} \mathrm{P}$-labelled probe $\mathrm{A}$ (lach), probe $\mathrm{B}($ lacZ) and probe $\mathrm{C}$ (lac $\mathrm{Y} / \mathrm{A})$. After washing at high stringency $\left[0.1 \times \mathrm{SSC}\right.$ (Maniatis $e$ t al., 1982) at $\left.65^{\circ} \mathrm{C}\right]$ the filters were exposed to X-ray film at $-70^{\circ} \mathrm{C}$ for $24 \mathrm{~h}$. The size of DNA which hybridized to probe B was determined using HindIII digests of $\lambda$ as standards.

utilizing a ColE1 replicon) was constructed, as described in Methods, and introduced into MC1061 carrying pHG9 (pHGl with Tn 1000 inserted in map position 1.5). Cells containing both plasmids only produced $\beta$-galactosidase in the presence of IPTG. Thus, the DNA region between map positions 1 and $2 \cdot 7$ encodes a protein which is trans acting and represses the $S$. bovis lac operon in the absence of IPTG or lactose.

Production of $\beta$-D-galactosidase in $S$. bovis is repressed by glucose. The regulation of the cloned gene was therefore investigated using $E$. coli $\mathrm{MC1061}$ containing pHGl. Wild-type $E$. coli W3110 was used as a control. Cells were cultured in L-broth with and without glucose, and $\beta$ D-galactosidase activity monitored (Table 3 ). Although the E. coli lac $Z$ gene was repressed by glucose, the metabolite had no effect on the corresponding $S$. bovis gene.

\section{Interspecies regulation of the $E$. coli and $S$. bovis lac operons}

The interaction of the $E$. coli repressor protein with the $S$. bovis operator was investigated. $E$. coli $\mathrm{MC} 1061$ containing the $E$. coli lacI gene, encoded by pNM52 (Gilbert et al., 1986), and pHG9, which contains the $S$. bovis lac operon but an inactive lacI gene, was grown in the presence and absence of IPTG and $\beta$-D-galactosidase activity determined. The results (Table 4) showed that the lac operon was induced 200 -fold by IPTG. The binding of the $S$. bovis lacI gene product to the $E$. coli lac operon was studied in a lacI strain of E. coli (CA159) harbouring pHG8 (contains the $S$. bovis lacI gene). $\beta$-D-Galactosidase was produced constitutively in CA159 but when the strain harboured pHG8 there was a 1000-fold induction of the enzyme in the presence of IPTG. Thus, the lac repressor protein from both bacteria shows interspecies activity.

\section{Isolation and nucleotide sequence of the $S$. bovis lac promoter}

The $4.5 \mathrm{~kb}$ Sst I-HindIII DNA restriction fragment was digested with TaqI, cloned into the $A c c$ I site of the promoter-probe vectors pNM480, pNM481 and pNM482, (Minton, 1984) and transformed into MC1061. Promotor activity was detected by the ability of recombinants to hydrolyse X-Gal. Promotor activity was detected when TaqI DNA restriction fragments were 


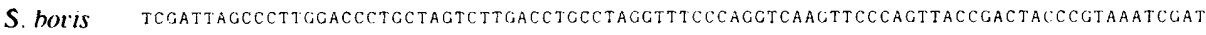

E. coli

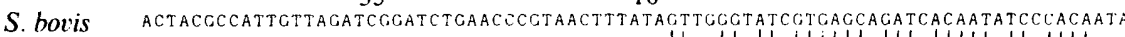

E. coli ACTACCCCATTCTTAGATCGGATCTCACCCGTAACTTTATAGTTGGGTATCGTCAGCAGATCACAATATCCCACAA -35
-35

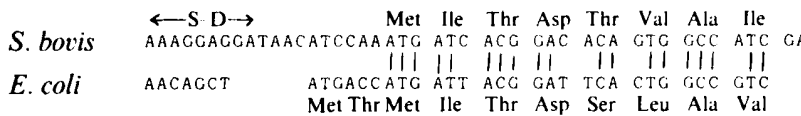

Fig. 4. Nucleotide sequences of $S$. bovis and $E$. coli lacop regions. Conserved nucleotides are linked by lines. The locations of specific features of the sequences are indicated by underlining and are labelled. The predicted amino sequence of the 5 ' region of the $\operatorname{lac} Z$ structural genes are also shown. S-D, ShineDalgarno region.

\section{Table 4. Interspecies regulation of the E. coli and $S$. bovis lac operons}

Recombinant plasmids were inserted into $E$. coli $\mathrm{MC1061}$ or CA159. The growth of recombinant strains, preparation of cell-free extracts and assay of $\beta$-D-galactosidase were as described in Table 3 .

\begin{tabular}{llcr} 
Strain & \multicolumn{1}{c}{ Plasmid } & $\begin{array}{c}\text { Addition to } \\
\text { growth medium }\end{array}$ & $\begin{array}{r}\beta \text {-D-Galactosid } \\
\text { [Units (mg pro }\end{array}$ \\
MC1061 & pHG9 & - & 4920 \\
MC1061 & pHG9 & IPTG & 5360 \\
MC1061 & pHG9/pNM52 & - & 13 \\
MC1061 & pHG9/pNM52 & IPTG & 3760 \\
CA159 & pHG8 & - & 150 \\
CA159 & pHG8 & IPTG & 24360 \\
CA159 & - & - & 29540 \\
CA159 & - & IPTG & 34620 \\
MC1061 & pHG10 & - & 1630 \\
MC1061 & pHG10 & IPTG & 1850 \\
MC1061 & pHG10/pHG8 & - & 16 \\
MC1061 & pHG10/pHG8 & IPTG & 1710
\end{tabular}

cloned into pNM480. Five recombinant plasmids of pNM480, containing promotor activity, were shown to have inserts of identical size (approximately $0.2 \mathrm{~kb}$ ). To investigate whether these sequences contained the $S$. bovis lac promotor/operator region, $\mathrm{MC1061}$ harbouring one of the recombinant plasmids ( $\mathrm{pHG10}$ ) was transformed with pHG8. The resultant strain was grown in the presence and absence of IPTG. The results (Table 4) showed that $\beta$-D-galactosidase was produced constitutively in the absence of pHG8, while in its presence IPTG induced a 100 -fold increase in enzyme activity. Thus, the promotorless $E$. coli $\beta$-D-galactosidase appears to be under the control of the $S$. bovis lac repressor protein, indicating that the $0.2 \mathrm{~kb}$ insert of $S$. bovis DNA encodes the lac promotor and operator regions.

The $S$. bovis lac regulatory sequence was removed from pNM480 by digestion with HindIII and $E c o$ RI, inserted into $\mathrm{M} 13 \mathrm{mp} 8$ and $\mathrm{M} 13 \mathrm{mp} 9$, and sequenced by the dideoxy chain termination method of Sanger et al. (1980). The positions of putative -10 and -35 promotor regions, operator and Shine-Dalgarno sequences, together with the corresponding $E$. coli regions, are shown in Fig. 4. There was strong homology between the operator sequences and the 5 ' sequences of the lac $Z$ structural genes (Kalnins et al., 1983). Little similarity between the -10 and -35 promotor regions was observed, and the CAP binding sequence of $E$. coli was absent in $S$. bovis DNA. The putative Shine-Dalgarno region of $S$. bovis was similar to the consensus ribosome binding sequence of Gram-positive bacterial mRNA (McLaughlin et al., 1981). 


\section{DISCUSSION}

The $S$. bovis lac genes were cloned and expressed in $E$. coli. Initially, the genes were located in a $7.8 \mathrm{~kb}$ HindIII restriction fragment, which was cloned into pBR322 in both orientations to give the recombinant plasmids $\mathrm{pHG} 1$ and $\mathrm{pHG}$ 2. E. coli harbouring either plasmid produced similar levels of lac catabolic proteins, indicating that the promotor region of the genes had also been cloned. The level of expression of the $\beta$-D-galactosidase gene in $E$. coli and $S$. bovis was similar. As there were 30-50 copies of pHG1 in E. coli (data not shown) and only a single copy of the lac $Z$ gene in $S$. bovis, it appears that the streptococcal promoter is not efficiently utilized in $E$. coli.

Data presented in this report showed that the three lac proteins were present in a constant ratio regardless of bacterial growth conditions. Transposon mutagenesis or deletion of the $\beta$-Dgalactosidase gene had a polar effect on the two other lac genes, while alteration of the lac permease gene only inactivated the transacetylase gene. Removal of the latter gene had no effect on $\beta$-galactosidase or lactose permease expression. The three lac proteins were induced by IPTG, but were synthesized constitutively when DNA sequences adjacent to the lac genes were altered. Thus, the three lac genes constitute an operon which is subject to negative control by a repressor protein whose gene is closely linked to the operon. $\beta$-D-Galactopyranosides inactivate the repressor protein; hence they induce synthesis of the Lac proteins. The levels of induction by IPTG (200-fold) of the $S$. bovis lac operon, either in $E$. coli or $S$. bovis, were similar. Thus, the lac repressor gene is expressed efficiently in $E$. coli. In contrast to this, the lac operons from certain enterobacteria are subject to anomalous expression in heterologous enterobacterial hosts because of low levels of the lacI protein (Baumberg \& Roberts, 1984; Baumberg et al., 1980).

The putative $S$. bovis lac promotor and operator has been cloned, sequenced and compared with the corresponding $E$. coli region. The putative $S$. bovis operator was very similar to the $E$. coli lacZo sequence. This provides an explanation for the strong interspecies activities of the lac repressor proteins from the two bacteria. That the CAP binding sequence present in $E$. coli lac $Z p$ was absent from the $S$. bovis promotor explains the lack of glucose repression of the streptococcal lac operon in E. coli. This is consistent with the observation that most Gram-positive bacteria do not synthesize cAMP (Lee et al., 1982). The mechanism of glucose repression exerted on the lac operon in $S$. bovis is unknown.

The homology between the lac $Z$ genes, and the similarity in the organization and regulation of the lac operons of the two bacteria, is surprising, as $S$. bovis is a Gram-positive rumen anaerobe, while $E$. coli is a Gram-negative enteric aerobe. Two possible explanations for these observations are: (i) the lac operon was transferred from an enteric bacteria to $S$. bovis via a transposon. The lac genes from the enteric bacterium Yersinia enterocolitica (Cornelis et al., 1978) are encoded by $\mathrm{Tn} 951$; (ii) $S$. bovis inherited the lactose catabolic pathway from enterobacterial plasmids such as those found in the genus Klebsiella (Brenchley \& Magasanik, 1972).

Future work in this laboratory will utilize the cloned $S$. bovis lac regulatory region to construct highly regulated expression vectors for this rumen micro-organism.

We wish to thank Newcastle University Research Committee for supporting Judith Hall.

\section{REFERENCES}

Armstrong, D. G. \& Gilbert, H. J. (1985). Biotechnology and the rumen: a mini review. Journal of the Science of Food and Agriculture 36, 1039-1046.

Bolivar, F., Rodriguez, R. L., Betlach, M. C. \& BOYER, H. W. (1977). Construction and characterization of new cloning vehicles. I. Ampicillinresistant derivative of the plasmid pMB9. Gene 2, 75-93.

BAUMberG, S. \& RoberTs, M. (1984). Anomalous expression of the $E$. coli lac operon in Proteus mirabilis. Molecular and General Genetics 198, 166171.
Baumberg, S., Cornelis, G., Panagiotakopoulos, M. \& ROBERTS, M. (1980). Expression of the lactose transposon Tn951 in Escherichia coli, Proteus and Pseudomonas. Journal of General Microbiology 119, 257-262.

Brenchley, J. E. \& Magasanik, B. (1972). Klebsiella aerogenes strain carrying drug resistance determinants and a lac plasmid. Journal of Bacteriology 112 , 200-205.

Chaconos, G., De Bruijn, F. J., Casadaban, M. J., LupsKi, J. R., KUOH, T. G., HARShey, R. M., DuBow, M. S. \& BUKhaRI, A. K. (1981). In vitro and 
in vivo manipulation of bacteriophage Mu DNA: cloning of $\mathrm{Mu}$ ends and construction of mini Mus carrying selectable markers. Gene 13, 37-46.

Chang, A. C. Y. \& Cohen, S. N. (1978). Construction and characterization of amplifiable multicopy DNA cloning vehicles derived from the P15A cryptic plasmid. Journal of Bacteriology 134, 1145-1156.

Clewell, D. B. \& HelinsKi, D. R. (1969). Supercoiled circular DNA-protein complex in E. coli. Purification and induced conversion to an open circular form. Proceedings of the National Academy of Sciences of the United States of America 62, 1159-1166.

Cohen, S. N., Chang, A. C. Y. \& Hsu, L. (1972). Nonchromosomal antibiotic resistance in bacteria: genetic transformation of $E$. coli by R-factor DNA. Proceedings of the National Academy of Sciences of the United States of America 69, 2110-2114.

Cornelis, G., Ghosal, D. \& SaEdler, H. (1978). Tn951: a new transposon carrying a lactose operon. Molecular and General Genetics 160, 215-224.

Gilbert, H. J., Clarke, I. N., Gibson, R. K., Stephenson, J. R. \& Tully, M. (1985). Molecular cloning of the phenylalanine ammonia-lyase gene from Rhodosporidium toruloides in Escherichia coli K-12. Journal of Bacteriology 161, 314-320.

Gilbert, H. J., Blazek, R., Bullman, H. M. S. \& Minton, N. P. (1986). Cloning and expression of the Erwinia chrysanthemi asparaginase gene in Escherichia coli and Erwinia carotovora. Journal of General Microbiology 132, 151-160.

GUYER, M. S. (1978). The sequence of $F$ is an insertion sequence. Journal of Molecular Biology 126, 347-365.

Hengstenberg, W., Penberthy, W. K., Hill, K. L. \& MORSE, M. L. (1969). Phosphotransferase system of Staphylococcus aureus: its requirement for the accumulation and metabolism of galactosides. Journal of Bacteriology 99, 383-388.

Holmes, D. S. \& Quigley, M. (1981). A rapid boiling method for the preparation of bacterial plasmid. Analytical Biochemistry 114, 193-197.

Kalnins, A., OtTo, K., Ruther, U. \& Muller-Hill, B. (1983). Sequence of the lacZ gene of Escherichia coli. EMBO Journal 2, 593-597.

LeE, L. L., HANSEN, J. B., JAGUSZTYN-KRYNICKA, E. K. \& ChassY, B. M. (1982). Cloning and expression of the $\beta$-D-phosphogalactoside galactohydrolase gene of Lactobacillus casei in Escherichia coli K12. Journal of Bacteriology 152, 1138-1146.

Loenen, W. A. \& Brammar, W. J. (1980). A bacteriophage lambda vector for cloning large DNA fragments made with several restriction enzymes. Gene 10, 249-259.

Mclaughlin, J. R., Murray, C. L. \& Rabinowitz, J. C. (1981). Unique features in the ribosome binding site sequence of the Gram positive Staphylo- coccus aureus $\beta$-lactamase gene. Journal of Biological Chemistry 256, 11283-11291.

Maeda, S. \& Gasson, M. J. (1986). Cloning, expression and location of the Streptococcus lactis gene for phospho- $\beta$-D-galactosidase. Journal of General Microbiology 132, 331-340.

Maniatis, Y., Fritsch, E. F. \& Sambrook, J. (1982). Molecular Cloning: a Laboratory Manual. Cold Spring Harbor, New York: Cold Spring Harbor Laboratory.

Meyers, J. A., Sanchez, D., Elwell, L. P. \& FALKOW, S. (1976). Simple agarose gel electrophoresis method for the identification and characterization of plasmid deoxyribonucleic acid. Journal of Bacteriology 127, 1529-1538.

MilleR, J. H. (1972). Experiments in Molecular Genetics. Cold Spring Harbor, New York: Cold Spring Harbor Laboratory.

MILLER, J. H. (1978). The Operon. Cold Spring Harbor, New York: Cold Spring Harbor Laboratory.

MinTon, N. P. (1984). Improved plasmid vectors for the isolation of translational lac gene fusions. Gene 31, 269-273.

Norrander, J., Kemp, T. \& Messing, J. (1983). Construction of improved M13 vectors using oligodeoxynucleotide-directed mutagenesis. Gene 26, 101-116.

Rigby, P. W. J., Dieckmann, M., Rhodes, C. \& Berg, P. (1977). Labelling deoxyribonucleic acid to high specific activity in vitro by nick translation with DNA polymerase 1. Journal of Molecular Biology 113, 237-251.

SANGer, F., Coulson, A. R., Barrell, B. G., Smith, A. J. H. \& ROE, B. A. (1980). Cloning in singlestranded bacteriophage as an aid to rapid DNA sequencing. Journal of Molecular Biology 143, 161178.

Silley, P. \& Armstrong, D. G. (1984). Changes in metabolism of the rumen bacterium Streptococcus botis $\mathrm{H} 13 / 1$ resulting from alteration in dilution rate and glucose supply per unit time. Journal of Applied Bacteriology 57, 345-353.

Smith, C. J. \& Hespell, R. B. (1983). Prospects for development and use of recombinant deoxyribonucleic acid techniques with ruminal bacteria. Journal of Dairy Science 66, 1536-1546.

Southern, E. M. (1975). Detection of specific sequences among DNA fragments separated by gel electrophoresis. Journal of Molecular Biology 98, 503-517.

VIERA, J. \& Messing, J. (1982). The pUC plasmids, an M13mp7-derived system for insertion mutagenesis and sequencing with synthetic universal primers. Gene 19, 259-269. 